\title{
Modelling spatial patterns of correlations between concentrations of heavy metals in mosses and atmospheric deposition in 2010 across Europe
}

Stefan Nickel ${ }^{1 *}$, Winfried Schröder ${ }^{1}$, Roman Schmalfuss ${ }^{1}$, Maike Saathoff ${ }^{1}$, Harry Harmens ${ }^{2}$, Gina Mills ${ }^{2}$, Marina V. Frontasyeva ${ }^{3}$, Lambe Barandovski ${ }^{4}$, Oleg Blum5, Alejo Carballeira6, Ludwig de Temmerman", Anatoly M. Dunaev ${ }^{8}$, Antoaneta Ene ${ }^{9}$, Hilde Fagerli ${ }^{10}$, Barbara Godzik ${ }^{11}$, Ilia Ilyin ${ }^{12}$, Sander Jonkers ${ }^{13}$,

Zvonka Jeran ${ }^{14}$, Pranvera Lazo ${ }^{15}$, Sebastien Leblond ${ }^{16}$, Siiri Liiv ${ }^{17}$, Blanka Mankovska ${ }^{18}$, Encarnación Núñez-Olivera ${ }^{19}$, Juha Piispanen ${ }^{20}$, Jarmo Poikolainen ${ }^{20}$, Ion V. Popescu ${ }^{21}$, Flora Qarri ${ }^{22}$, Jesus Miguel Santamaria ${ }^{23}$, Martijn Schaap ${ }^{13}$, Mitja Skudnik ${ }^{24}$, Zdravko Špirić ${ }^{25}$, Trajce Stafilov ${ }^{4}$, Eiliv Steinnes ${ }^{26}$, Claudia Stihi ${ }^{21}$, Ivan Suchara ${ }^{27}$, Hilde Thelle Uggerud ${ }^{28}$ and Harald G. Zechmeister ${ }^{29}$

\begin{abstract}
Background: This paper aims to investigate the correlations between the concentrations of nine heavy metals in moss and atmospheric deposition within ecological land classes covering Europe. Additionally, it is examined to what extent the statistical relations are affected by the land use around the moss sampling sites. Based on moss data collected in 2010/2011 throughout Europe and data on total atmospheric deposition modelled by two chemical transport models (EMEP MSC-E, LOTOS-EUROS), correlation coefficients between concentrations of heavy metals in moss and in modelled atmospheric deposition were specified for spatial subsamples defined by ecological land classes of Europe (ELCE) as a spatial reference system. Linear discriminant analysis (LDA) and logistic regression (LR) were then used to separate moss sampling sites regarding their contribution to the strength of correlation considering the areal percentage of urban, agricultural and forestry land use around the sampling location. After verification LDA models by LR, LDA models were used to transform spatial information on the land use to maps of potential correlation levels, applicable for future network planning in the European Moss Survey.
\end{abstract}

Results: Correlations between concentrations of heavy metals in moss and in modelled atmospheric deposition were found to be specific for elements and ELCE units. Land use around the sampling sites mainly influences the correlation level. Small radiuses around the sampling sites examined $(5 \mathrm{~km})$ are more relevant for $\mathrm{Cd}, \mathrm{Cu}, \mathrm{Ni}$, and $\mathrm{Zn}$, while the areal percentage of urban and agricultural land use within large radiuses $(75-100 \mathrm{~km})$ is more relevant for $\mathrm{As}, \mathrm{Cr}, \mathrm{Hg}, \mathrm{Pb}$, and V. Most valid LDA models pattern with error rates of $<40 \%$ were found for $\mathrm{As}, \mathrm{Cr}, \mathrm{Cu}, \mathrm{Hg}, \mathrm{Pb}$, and $\mathrm{V}$. Land use-dependent predictions of spatial patterns split up Europe into investigation areas revealing potentially high (=above-average) or low (= below-average) correlation coefficients.

Conclusions: LDA is an eligible method identifying and ranking boundary conditions of correlations between atmospheric deposition and respective concentrations of heavy metals in moss and related mapping considering the influence of the land use around moss sampling sites.

\footnotetext{
${ }^{*}$ Correspondence: stefan.nickel@uni-vechta.de

${ }^{1}$ Chair of Landscape Ecology, University of Vechta, Vechta, Germany

Full list of author information is available at the end of the article
} 
Keywords: Biomonitoring, Chemical transport models, Correlation analysis, Ecological classification, Linear

discriminant analysis, Logistic regression

\section{Background}

The United Nations Economic Commission for Europe (UNECE) Convention on Long-range Transboundary Air Pollution (CLRTAP) of 1979 and its eight protocols are aimed at limiting and reducing air pollutants. Under the LRTAP convention, the European monitoring and evaluation programme (EMEP) gathers information on emission from its parties, collects data on air and precipitation quality and models atmospheric transport and deposition of air pollutants [1]. Beyond this, biomonitoring programmes provide data on concentrations in various biological matrices potentially correlated with atmospheric deposition of heavy metals (HM). Within the LRTAP convention, European Moss Survey (EMS) is conducted using naturally growing mosses as biomonitors of atmospheric deposition of air pollutants. Since 1990, moss specimens have been sampled every 5 years at up to 7300 sampling sites in up to 35 countries [2-4] to determine the concentrations of heavy metals (HM), nitrogen (N, since 2005) and persistent organic pollutants (POPs, since 2010) $[4,5]$. The EMS is coordinated by the ICP Vegetation, an international cooperative programme (ICP) reporting on impacts of air pollution on vegetation to the LRTAP convention [3].

Based on EMS data from 2005, atmospheric deposition has been identified as the main factor determining the spatial variation of concentrations of cadmium $(\mathrm{Cd})$ and lead $(\mathrm{Pb})$ in moss specimens collected throughout Europe [6-8]. Harmens et al. [9] found significant correlations between $\mathrm{Cd}$ and $\mathrm{Pb}$ concentration in moss and respective atmospheric deposition modelled by EMEP for more than two-thirds of the countries participating in the European Moss Survey. Schröder et al. [10] correlated $\mathrm{Cd}$, mercury $(\mathrm{Hg})$, and $\mathrm{Pb}$ concentrations in deposition and moss data from the EMS 2005 within a spatial framework of ecologically defined land classes by use of the numeric chemical transport model (CTM) of EMEP MSC-East [11]. In further studies, also land use around the sampling sites is shown to be an important factor affecting element concentrations in moss [12-14].

The above-mentioned findings were verified in the investigation presented in this paper using data collected in the EMS 2010. The present study addresses the following objectives.

1. Correlation analysis Examination of correlations between concentrations of $\mathrm{HM}$ in moss from the EMS 2010/2011 and respective atmospheric deposi- tion as modelled by use of the CTMs EMEP MSCEast and LOTOS EUROS (LE), and to which extent the correlations are specific for ecological land classes of Europe (ELCE) [15].

2. Statistical modelling Calculation, to which extent the amount of ELCE-specific correlation coefficients is affected by the areal percentage of land use around the sampling sites potentially indicating influences of local emission sources as for instance agricultural and urban land use or point sources of air pollutants. Hence, the reason for different ELCE-specific correlation coefficients was investigated.

3. Predictive mapping Land use-dependent predictions and mapping of correlation patterns across Europe (site-related/area-related) and, finally, aggregation of predicted spatial patterns for decision support (e.g. moss survey network planning).

For this investigation, data on atmospheric deposition of HM derived from the EMEP MSC-East [11] were supplemented by deposition data calculated by use of the chemical transport model LOTOS-EUROS (LE) [16].

\section{Methods}

Data on element concentration in moss were correlated with respective modelled atmospheric deposition specifically for ecological land classes of Europe (ELCE) and major land use categories around the sampling sites derived from CORINE land cover 2006 and Global land cover 2000 [17, 18] (Table 1).

\section{Data on element concentrations in moss}

In 2010/2011, moss specimens were collected at 4499 sample sites in 26 countries across Europe following a standardized experimental protocol [19]. Further countries like Germany, Ireland and United Kingdom who participated in former moss surveys did not participate in 2010. To provide field-based evidence of the extent of long-range transboundary pollution in Europe the monitoring sites are located in background areas, e.g. sampling sites were at least $300 \mathrm{~m}$ away from major roads and $100 \mathrm{~m}$ away from any road or houses. Primarily, Pleurozium schreberi (Brid.) Mitt., Hylocomium splendens (Hedw.) Schimp., Hypnum cupressiforme Hedw. s.str. and Pseudoscleropodium purum (Hedw.) M. Fleisch (synonym Scleropodium purum Hedw. Limpr.) [20] were sampled, but also 32 other species (7\% of the samples). For each site, at least five individual moss samples of the 
Table 1 Data used for statistical analysis

\begin{tabular}{|c|c|c|}
\hline Data & Comment and source & Unit \\
\hline Element concentration in moss & As, Cd, Cr, Cu, Hg, Ni, Pb, V, and Zn conc. in moss from the European Moss Survey 2010/2011 & $\mu \mathrm{g} / \mathrm{g}$ \\
\hline \multirow[t]{2}{*}{ Atmospheric deposition } & $\begin{array}{l}\text { Modelled total deposition of As, Cd, Cr, Cu, Ni, Pb, V, Zn summed over } 3 \text { years (LOTOS-EUROS } \\
\text { 2009-2011, [21]) }\end{array}$ & $\mu \mathrm{g} / \mathrm{m}^{2}$ \\
\hline & $\begin{array}{l}\text { Modelled total atmospheric deposition of Cd, Hg, Pb (EMEP MSC-East) summed over } 3 \text { years (EMEP } \\
\text { 2008-2010) }\end{array}$ & $\mu \mathrm{g} / \mathrm{m}^{2}$ \\
\hline $\mathrm{ELCE}_{40}$ & Ecological land classes of Europe [15] & 40 land classes \\
\hline $\begin{array}{l}\text { Spatial density of land use } \\
\text { around moss sampling sites }\end{array}$ & $\begin{array}{l}\text { Areal percentage of urban, agricultural, and forestry land use, each within a 1, 5, 10, 25, 50, 75, and } \\
100 \mathrm{~km} \text { radius around the moss sampling sites, derived from CORINE land cover } 2006 \text { [17] and } \\
\text { global land cover } 2000 \text { [18] for Russia, Ukraine and Belarus }\end{array}$ & $\%$ \\
\hline
\end{tabular}

${ }^{\text {a }}$ HM data provided by MSC-East (November 2013)

same species were collected. Only the 2- to 3-year-old shoots of the mosses were used for the analyses. Concentrations of nine HMs: arsenic (As), cadmium (Cd), chromium $(\mathrm{Cr})$, copper $(\mathrm{Cu})$, mercury $(\mathrm{Hg})$, nickel $(\mathrm{Ni})$, lead $(\mathrm{Pb})$, vanadium $(\mathrm{V})$, and zinc $(\mathrm{Zn})$ were determined $[4,9]$.

\section{Data on atmospheric deposition}

Statistical relations between element concentrations in moss and atmospheric deposition of HM derived from the numeric chemical transport models (CTMs) LOTOSEUROS (LE) [16, 21] and EMEP [11] were examined. CTMs are based on mathematical descriptions of relevant physical and chemical processes in the atmosphere and are mostly used for large-scale, area-wide estimates of atmospheric deposition [21]. The accuracy of deposition modelling basically depends on the quality of the input data (emission, meteorology, land use, other conditions) used for modelling atmospheric transport and deposition processes as well as intrinsic model uncertainties.

The EMEP deposition data were supplied by the meteorological synthesizing centres MSC-East (Moscow) of EMEP operating under the LRTAP convention. Travnikov and Ilyin [11] used emission data to calculate atmospheric deposition of $\mathrm{Cd}, \mathrm{Hg}$, and $\mathrm{Pb}$. To verify these model calculations, the results were compared to $\mathrm{Cd}$ and $\mathrm{Pb}$ measurement data from up to 66 EMEP sites and to $\mathrm{Hg}$ data collected at up to 22 EMEP sites [22]. The verified model results were then mapped on grids of $50 \mathrm{~km} \times 50 \mathrm{~km}[11]$.

Following Harmens et al. [9], in this investigation the 3-year sum of HM deposition modelled by EMEP (on a $50 \mathrm{~km}$ by $50 \mathrm{~km}$ grid) corresponds to the HM concentration in the sampled 3-year-old shoots of the mosses. Here, the deposition data from 2008 to 2010 was assigned to the data collected in EMS 2010/2011. The 3-year sums of deposition 2009-2011 from LE [16, 21] were assigned to the concentrations of HM in moss collected in EMS 2010/2011. LE provides deposition rates of As, Cd, Cr, $\mathrm{Cu}, \mathrm{Ni}, \mathrm{Pb}, \mathrm{V}$, and $\mathrm{Zn}$ on a $25 \mathrm{~km}$ by $25 \mathrm{~km}$ grid covering
Europe. Additional information about the CTM is given in Additional file 1: Table S2.

\section{Ecological land classification of Europe}

The data on element concentrations in moss and atmospheric deposition were spatially joined to the map of ecological land classes of Europe (ELCE) (Additional file 1: Figure S1, Table S1) derived from Hornsmann et al. [15]. According to the level of spatial differentiation, the ecological classification encompasses $40\left(\mathrm{ELCE}_{40}\right)$ to 200 $\left(\mathrm{ELCE}_{200}\right)$ classes identified by 48 geo-data layers on potential natural vegetation [23], altitude above sea level [24], soil texture [25], and monthly averages of precipitation and air temperature (1961-2002) [26]. ELCE $\mathrm{EL}_{40}$ and ELCE $_{200}$ were calculated and mapped by means of classification and regression trees [27]. To ensure the best possible compliance with minimum sample size specified for each ecoregion [28, 29], ELCE $\mathrm{E}_{40}$ was used, whereby ELCE units occurring sporadically and with a total spatial extent below $4.2 \%$ were summarized to one class ("others").

\section{Statistical analysis Correlation analysis}

The statistical design comprises the calculation of Spearman rank correlation coefficients $\left(r_{s}\right)$ for quantifying the relation between concentrations in mosses and modelled atmospheric deposition of HM and $\mathrm{N}$ (Fig. 1). The measured concentrations of $\mathrm{As}, \mathrm{Cd}, \mathrm{Cr}, \mathrm{Cu}, \mathrm{Hg}, \mathrm{Ni}, \mathrm{Pb}, \mathrm{V}$, and $\mathrm{Zn}$ in moss were correlated with respective total atmospheric deposition data as modelled by EMEP and LE. Thereby, ecological land classes $\left(\mathrm{ELCE}_{40}\right)$ within participating European countries were used as coding variable for calculating ELCE-specific correlations. Due to a nonnormal distribution in most of the subsamples, Spearman rank correlation coefficients $\left(r_{\mathrm{s}}\right)$ were determined. The correlation coefficients were classified according to Brosius [30] as very weak $(<0.2)$, weak $(0.2-0.4)$, moderate (0.4-0.6), strong (0.6-0.8), and very strong $(>0.8)$. 


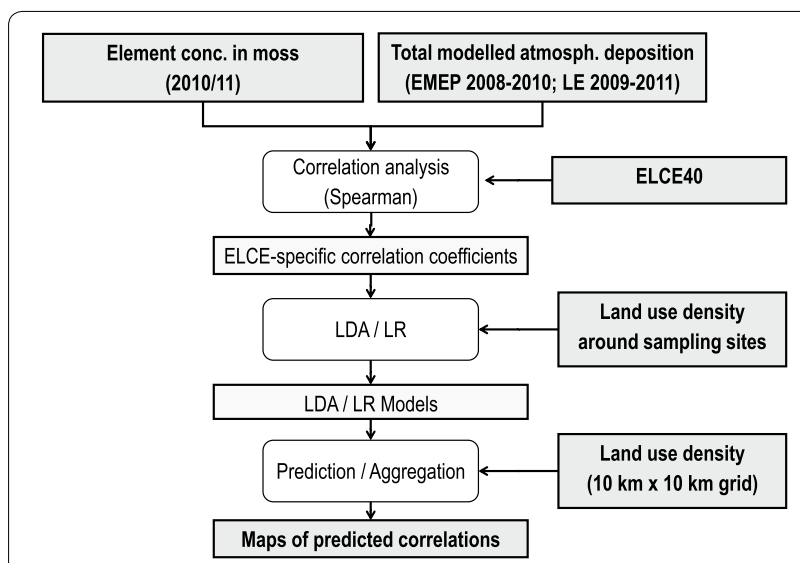

Fig. 1 Design of statistical analysis (LDA linear discriminant analysis, $L R$ logistic regression)

\section{Linear discriminant analysis/logistic regression}

The second step is to investigate the reason for the difference of ELCE-specific correlations. LDA models were used to find linear separation lines as best discriminate of sampling sites in ELCE regions revealing high or low element-specific correlation coefficients. LDA attempts to find a multivariate discriminant function $Y=b_{0}+b_{1} X_{1}+b_{2} X_{2}+\cdots$ describing a linear combination of two or more predictors $\left(X_{1}, X_{2}, \ldots\right)$ and respective coefficients $\left(b_{0}, b_{1}, b_{2}, \ldots\right)$. The aim is to separate groups of data in a scatterplot so that the variation in data within each group is minimized [31-33] and express the contribution of each predictor in the selected discriminant model. For binary classification of ELCE and their allocated sampling sites showing high $(=\mathrm{A})$ or low $(=\mathrm{B})$ correlations, medians of the ELCE-specific Spearman coefficients were taken for defining element-specific class boundaries between high and low correlation levels. ELCE with coefficients above the class boundaries in terms of element-specific medians were classified as ' $\mathrm{A}$ ' and ELCE below the class boundaries as 'B'. Twenty-one variables for spatial density of agricultural, forestry, and urban land use within a 1, 5, 10, 25, 50, 75, and $100 \mathrm{~km}$ radius around the sampling sites (Table 1) were taken as potential predictors for HM concentrations in moss samples. As the target variable is already determined by atmospheric deposition, it was not considered as a predictor. Further potential influencing factors like elevation, precipitation, population density as investigated by Nickel et al. [34] were examined in a pre-analysis using LDA, but were excluded due to low relevance. Since the values of each of these predictors range between 0 and $100 \%$, data did not need to be standardized as recommended for LDA by Schönwiese [35]. Overall, twelve LDA models were built with regard to available EMEP deposition values for $(\mathrm{Cd}, \mathrm{Pb}, \mathrm{Hg})$ and LOTOS-EUROS deposition estimations for $\mathrm{As}, \mathrm{Cd}, \mathrm{Cr}, \mathrm{Cu}, \mathrm{Ni}, \mathrm{Pb}, \mathrm{V}$, and $\mathrm{Zn})$. It was examined whether the variance could be sufficiently explained by just two of the potential 21 linear discriminants (=spatial density [\%] of urban, agricultural, and forestry land use, each within a 1, 5, 10, 25, 50, 75 , and $100 \mathrm{~km}$ radius around the moss sampling sites, Table 1) to keep the models as simple as possible and allowing for a better interpretation and visualization of the results. Here, near-zero coefficients (linear combination coefficient ranges between -1 and 1 ) and correlated predictors have been removed to avoid multicollinearity. For example, if the coefficient of urban land use within a $10 \mathrm{~km}$ radius was closer to zero than the $5 \mathrm{~km}$ coefficient, the latter was taken.

Logistic regression (LR) is similar to LDA, as it also explains a categorical variable by the values of continuous independent variables. LR is preferable in applications where the independent variables are not normally distributed. Since LR is less concrete, LDA in the present study was used for model building and LR for verification of LDA results.

\section{Predictions}

LDA models were firstly applied on the Europe-wide dataset of moss sampling sites with information on land use density around the sampling sites. Model-specific error rates (\%) were calculated by means of confusion matrix values (actual vs. predicted values). Charts for the linear discriminant functions were used for plausibility checks. Logistic regression models were built using the same predictors from the LDA models. Confusion matrices and error rates (\%) specified for each LR model were calculated and compared with the statistical characteristics of the LDA models.

To verify to which extent the models really separate sampling sites showing high or low correlations between element concentrations in moss and respective atmospheric deposition, bivariate Spearman coefficients for the correlations between element concentrations in moss and atmospheric deposition were again calculated for the following subsamples: sampling sites located within all ELCE classes, ELCE classes showing correlations above and below the element-specific class boundaries between high and low correlation levels defined in Table 1. Each subsample was further divided into groups of sampling sites classified by LDA into category A or B. The more B sampling sites modelled by LDA show low or, vice versa, A sites reveal high correlations, the more efficient the between-class separation through the modelling and thus the relevance of predictors.

Geographic information on the spatial density of agricultural, forestry, and urban land use within a 1, 5, 10, 
$25,50,75$, and $100 \mathrm{~km}$ radius around the sampling sites available with blanket coverage of Europe was taken as predictors for estimating categories of correlations (A, B) between atmospheric deposition of nine HM in Europe using LDA models and to transform spatial information on the land use to spatial correlation patterns across Europe. Finally, spatial patterns estimated by the best LDA models were aggregated by calculating the number of element-specific A classifications (=above elementspecific class boundaries between high and low correlation levels as defined in Table 2) to reduce complexity which is more appropriate for decision support. All statistical analyses were performed using $\mathrm{R}$ programming language [36], in particular functions for LDA as implemented in the 'MASS' package extending R's core functionality [37].

\section{Results}

Correlations between HM concentrations in moss and atmospheric deposition for ELCE categories across Europe and for Europe as a whole

All analyses with HM concentration in moss were based on a reasonably large sample size of at least 3274 (As) out of $3965(\mathrm{Zn})$ sample points. The minimum sample sizes for elements and $\mathrm{ELCE}_{40}$ classes were calculated and presented by Schröder et al. [28, 29]. As the number of moss sampling sites was very low ( $>10$ in the classes D_16, D_21, L_2, M_5, and M_6), the correlations for these classes are not considered reliable and are not described below. However, these four classes altogether represent only $2.3 \%\left(=69,600 \mathrm{~km}^{2}\right)$ of the sampled area in the countries participating in the EMS $\left(=3,083,500 \mathrm{~km}^{2}\right)$.

\section{Cadmium}

Strong correlations between element concentrations measured in moss and modelled deposition (EMEP, LE) with coefficients $\left(r_{\mathrm{s}}\right)$ ranging from 0.6 to 0.8 were achieved for 7\% (EMEP) up to $10.5 \%$ (LE) of the area of $\mathrm{ELCE}_{40}$ coverage of all countries participating in the EMS 2010 together (Table 2). These ELCE 40 categories (D_13, F1_1, S_0, and "others") are located in Poland, Switzerland and Austria (Fig. 2). The strength of the Europe-wide correlation is also high $\left(r_{\mathrm{s}}=0.65, p<0.01\right)$. Moderate $\mathrm{r}_{\mathrm{s}}$ values occurred for $\mathrm{ELCE}_{40}$ units covering 47.0-49.6\% of the landmass. Moss data from each $5 \mathrm{ELCE}_{40}$ (for LE in parts other than for EMEP) are weakly correlated with the modelled Cd deposition (EMEP: 15.0\%; LE: 17.5\%). 7 (EMEP) up to 9 (LE) out of $27 \mathrm{ELCE}_{40}$ units reveal nonsignificant or very weak correlations (23.5-31.1\%).

\section{Lead}

For $\mathrm{Pb}$, in 4 (EMEP) up to 6 (LE) out of $27 \mathrm{ELCE}_{40}$ units the $r_{\mathrm{s}}$ values were not significant $(12.0-20.3 \%$ of area of
ELCE units covered by moss sampling sites) (Table 2). From the remaining $\mathrm{ELCE}_{40}$ classes, 6 (in case of LE, 26.3\%) and 7 (EMEP, 28.9\%) ELCE units show Spearman's rank coefficients between 0.2 and 0.4. For another 10 ELCE categories (LE) and, respectively, 11 ELCE categories (EMEP), correlation coefficients came out to be between 0.4 and 0.6 . The area comprises $36.6-43.5 \%$ of the total area covered by moss samples mainly located in Finland, Sweden and France (Fig. 2). Highest correlations $\left(0.6>r_{\mathrm{s}}>0.8\right)$ were found for max. 5 ELCE classes: D_13 (only EMEP), S_0 (only LE), B_2, C_0, F1_1, "others" (both EMEP and LE) (15.6-16.8\% of the landmass) predominately distributed in Norway. With regard to the samplings across Europe, Spearman's rank coefficients are 0.64 (LE) and 0.7 (EMEP).

\section{Mercury}

For $\mathrm{Hg}$, in 21 out of 27 ELCE units, the $r_{\mathrm{s}}$ values were not significant, below 0.02 or even negative $(82.5 \%$ of area of ELCE classes covering all participating countries together). It is clear that the correlation between moss data from the EMS 2010 and EMEP modelled deposition is very low $\left(r_{\mathrm{s}}=0.14\right.$, Table 2$)$. Above-average correlations with coefficients between 0.4 and 0.6 were only found for ELCE units B_1, D_14, F4_1, and J_2 (9.2\% of the area), sparsely located in Fennoscandia, Estonia, Poland, France and Spain (Fig. 2). For another 2 ELCE classes (D_7, F1_1), correlation coefficients were between 0.2 and 0.4 , comprising $8.3 \%$ of the area covered by moss samples.

\section{Arsenic}

For Europe as a whole, low correlations between As concentrations in moss and respective modelled atmospheric deposition (LOTOS-EUROS) were found $\left(r_{\mathrm{s}}=0.3\right) .14$ out of $27 \mathrm{ELCE}_{40}$ units reveal non-significant correlations within $41.1 \%$ of the sampled ELCE $_{40}$ area (Table 2). In 5 out of the remaining $13 \mathrm{ELCE}_{40}$ units, variables were negatively correlated (30.1\%). Three $\mathrm{ELCE}_{40}$ classes reveal significant weak correlations with $r_{\mathrm{s}}$ values between 0.2 and $0.4(13.1 \%)$. Merely 4 ELCE $_{40}$ units show moderate coefficients between 0.4 and 0.6 (C_0, D_17, D18, and $\left.\mathrm{F} 1 \_1\right)$. The $\mathrm{ELCE}_{40}$ unit with the highest correlation was U_1 $\left(r_{\mathrm{s}}=0.72, p<0.01\right)$ comprising dispersed small areas within the participating countries (1\%) (Fig. 3).

\section{Chromium}

Of all elements examined, $\mathrm{Cr}$ reveals the weakest Europewide correlation between concentrations in moss and total deposition modelled by LE $\left(r_{\mathrm{s}}=0.03\right.$, Table 2$)$. For 16 out of $27 \mathrm{ELCE}_{40}$ units, the $\mathrm{r}_{\mathrm{s}}$ values were not significant $(49.5 \%$ of area of ELCE units covered by moss sampling sites), and for $37.3 \%$, the $r_{s}$ values were below 0.02 


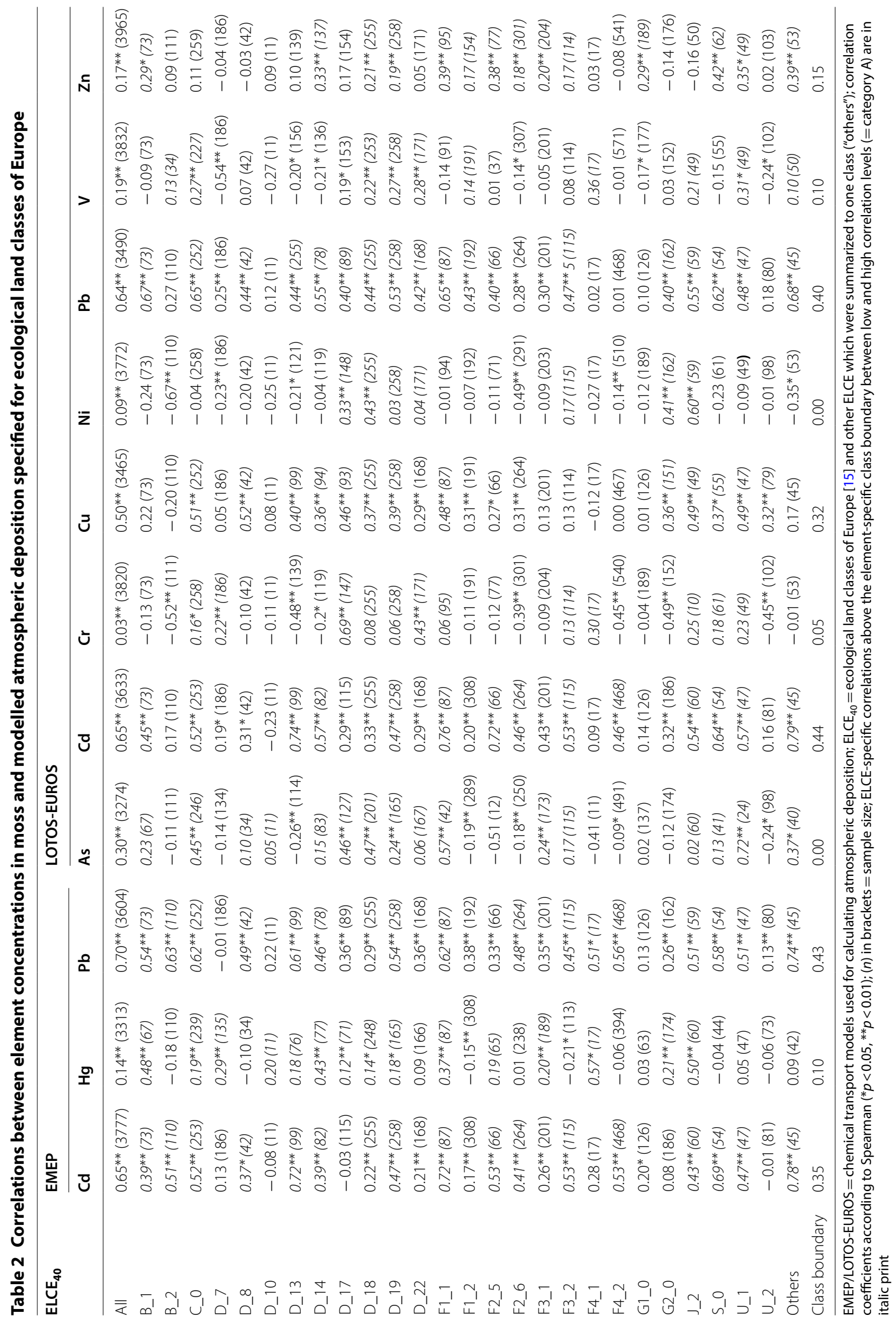



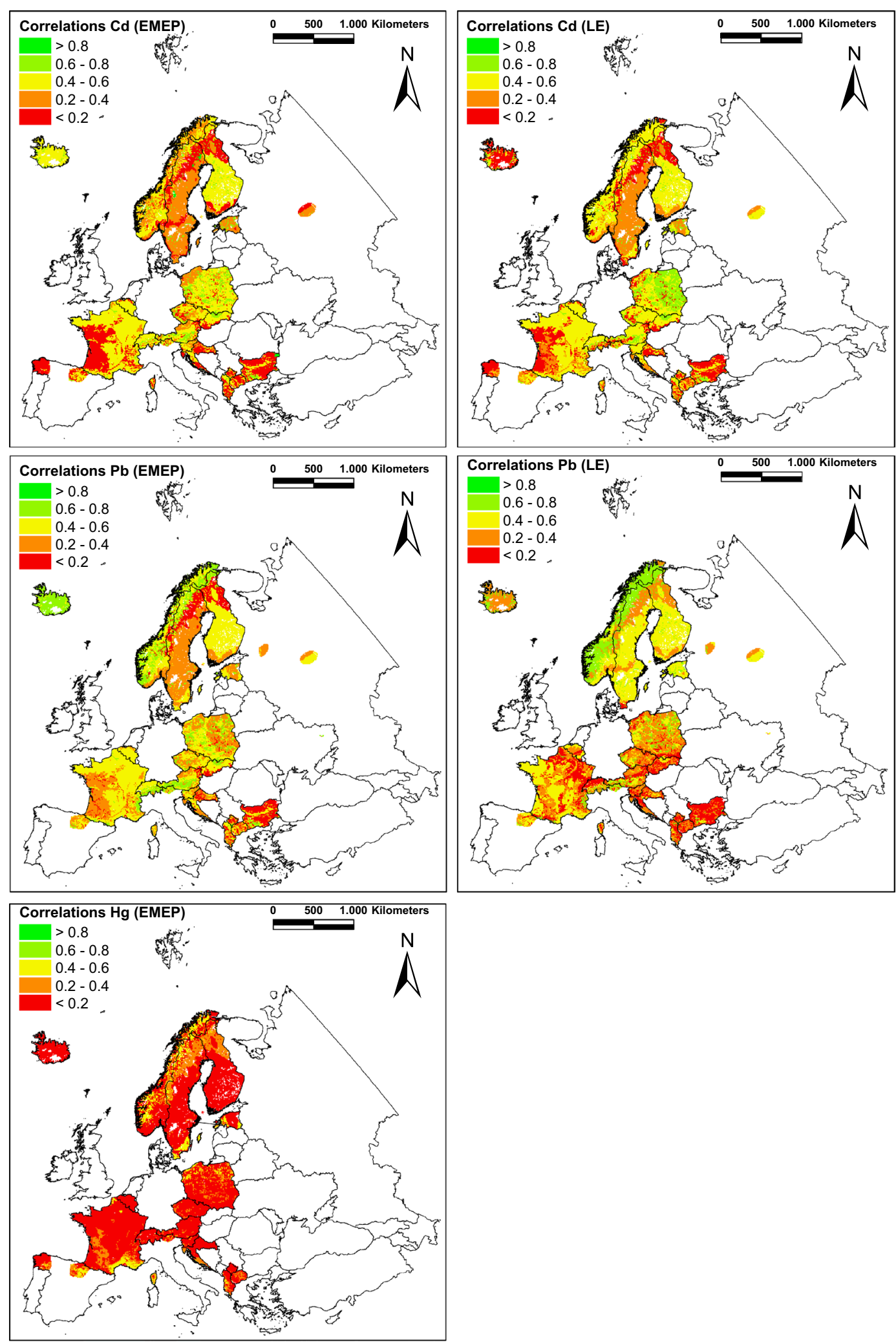

Fig. 2 ELCE-specific correlations of $\mathrm{Cd}, \mathrm{Pb}$ and $\mathrm{Hg}$ concentrations in mosses and respective modelled atmospheric deposition. Atmospheric deposition was modelled by LE (2009-2011) or EMEP (2008-2010); concentration values in mosses were determined in 2010 

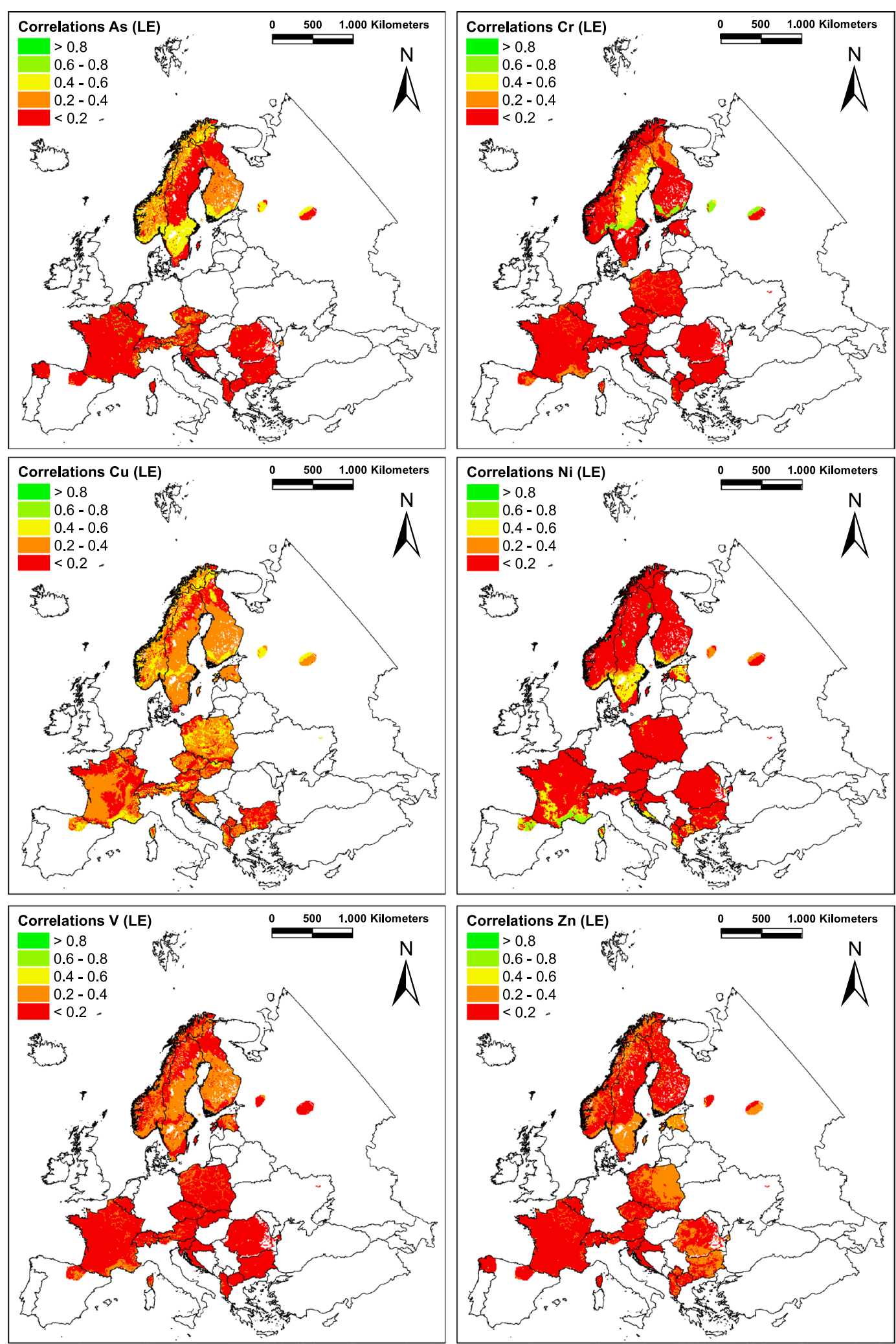

Fig. 3 ELCE-specific correlations of As, $\mathrm{Cr}, \mathrm{Cu}, \mathrm{Ni}, \mathrm{V}$ and $\mathrm{Zn}$ concentrations in mosses and respective modelled atmospheric deposition. Atmospheric deposition was modelled by LE (2009-2011) or EMEP (2008-2010); concentration values in mosses were determined in 2010 
or even negative (Fig. 3). A strong correlation $\left(r_{\mathrm{s}}=0.69\right)$ could be shown for land class D_17, covering $2.4 \%$ of the analysed area, located in Sweden, Finland and Russia. D_22 (5.4\%) as a part of Sweden reveals at least moderate correlations $\left(r_{\mathrm{s}}=0.43\right)$. The remaining surface showing low correlations is allocated to ELCE unit D_7, which covers $5.4 \%$ of the landmass.

\section{Copper}

The largest area covered by moss sampling sites (48.9\%) is allocated to low correlations $\left(r_{\mathrm{s}}\right)$ between 0.2 and 0.4 . Moderately strong correlations were found for 6 out of $27 \mathrm{ELCE}_{40}$ units (C_0, D_8, D_17, F1_1, J_2, and U_2) sparsely distributed in almost every participating country and comprising $15.6 \%$ of the ELCE units. In comparison, Europe as a whole is also characterized by an intermediately strong correlation $\left(r_{\mathrm{s}}=0.5\right)$. All other 10 out of 27 ELCE $_{40}$ units reveal non-significant correlations within $35.5 \%$ of the sampled $\mathrm{ELCE}_{40}$ area.

\section{Nickel}

For $\mathrm{Ni}$, most of the $\mathrm{ELCE}_{40}$ units reveal negative correlations (28.5\% of the analysed area) or non-significant values (53.8\%). Significant positive correlations in $\mathrm{ELCE}_{40}$ classes were found for D_17 $\left(0.2>r_{\mathrm{s}}>0.4\right), \mathrm{D} \_18, \mathrm{G} 2 \_0$ $\left(0.4>r_{\mathrm{s}}>0.6\right)$ and J_2 $\left(0.6>r_{\mathrm{s}}>0.8\right)$ (Table 2). Together, these four land classes comprise only $13.1 \%$ of the ELCE territory within participating countries, in particular Sweden, Estonia and France (Fig. 3). Overall, this corresponds to a very low correlation of $r_{\mathrm{s}}=0.09$ across Europe.

\section{Vanadium}

With respect to atmospheric $\mathrm{V}$ deposition modelled by LE and respective concentration in moss, merely 5 of 31 $\mathrm{ELCE}_{40}$ classes (plus "others") reveal significant positive, low Spearman's rank coefficients (C_0, D_18, D_19, D_22, and U_1). They cover $25.7 \%$ of the sampled area and can be primarily found in Fennoscandia, northern Spain and France (Fig. 3). 2.4\% of the area analysed (D_17) shows significant low correlations. The remaining ELCE units $(66.8 \%)$ reveal non-significant or negative correlations (Table 2). For V across Europe, the Spearman coefficient also has to be classified as low and amounts to $r_{\mathrm{s}}=0.19$.

\section{Zinc}

On the European level, the correlation between modelled $\mathrm{Zn}$ deposition (LE) and concentrations in moss is significantly low with $r_{\mathrm{s}}=0.17$. The only $\mathrm{ELCE}_{40}$ unit with an intermediately high correlation is S_0, located in parts of Estonia, Finland and Russia (1.4\% of the sampled area). The 7 out of $26 \mathrm{ELCE}_{40}$ classes with at least low correlations were the following: D_18, F1_1, F2_5, F3_1, G1_0,
U_1, and "others", located in eastern and northern parts Europe. The coefficients for the remaining ELCE units are very low or non-significant $(29.5 \%$ and $45.6 \%$ of the landmass).

\section{Linear discriminant analysis/logistic regression}

The frequency of the predictors used as discriminants in the 11 LDA models ranges between 1 and 3 , which means that none of the factors in particular stands out (Fig. 4). Moreover, the relevance of the predictors for separating sampling sites contributing to high or low correlations is element specific. When taking areal percentage of urban and agricultural land use as indicators for potential influences of areal and point emission sources, small radiuses around the sampling sites $(5 \mathrm{~km})$ are obviously more relevant for $\mathrm{Cd}, \mathrm{Cu}, \mathrm{Ni}$, and $\mathrm{Zn}$ than that for the other elements examined. Vice versa, areal percentage of urban and agricultural land use within large radiuses $(75-100 \mathrm{~km})$ is more relevant for $\mathrm{As}, \mathrm{Cr}, \mathrm{Hg}, \mathrm{Pb}$, and $\mathrm{V}$.

LDA models with the highest quality corresponding to error rates $\leq 30 \%$ were found for $\mathrm{Cr}$ and $\mathrm{V}$ followed by $\mathrm{As}, \mathrm{Cu}, \mathrm{Hg}$, and $\mathrm{Pb}$ (only LE) with error rates $\leq 40 \%$ (Table 3), i.e. in 7 out of 11 cases $<40 \%$ of the sampling sites has been incorrectly classified according to their surrounding land use. Although all predictors were not normally distributed, which is a fundamental assumption for LDA, error rates of the logistic regression models (LR) using the same predictors as the LDA models were very similar.

From Tables 2 and 3, it is obvious that LDA models are appropriate, particularly in case of elements showing low correlations between atmospheric deposition and concentrations in moss $(\mathrm{Cr}, \mathrm{Cu}, \mathrm{Hg}, \mathrm{V})$. For $\mathrm{Cd}$ and $\mathrm{Pb}$ with strong correlations, density of land use around the sampling sites seems to be less relevant. This is also confirmed by the statistical indicators for the significance of the predictors given from LR modelling: Density of urban land use $(5 \mathrm{~km})$ for Cd (EMEP, LE) and agricultural land use $(100 \mathrm{~km})$ as a predictor for $\mathrm{Pb}$ (EMEP) was both nonsignificant, which may also explain the high error rates of $41-44 \%$.

Figure 4 shows the discriminant lines obtained from LDA. The 11 scatter plots exemplify the separation between sampling sites contributing to high and low correlation. Since the whole set of ELCE would lead into non-readable graphs, ELCE units with maximum and minimum correlation coefficients have been selected as examples. Error rates of 26-44\% (Table 3) are reflected in discriminant lines not really separating green and red points. Resulting from this, LDA models for $\mathrm{As}, \mathrm{Cr}, \mathrm{Cu}$, $\mathrm{Hg}, \mathrm{Pb}$, and $\mathrm{V}$ prove to be the most appropriate. The location of point clusters in case of $\mathrm{Ni}$ and $\mathrm{Zn}$ appears to be implausible, because low densities of urban and 

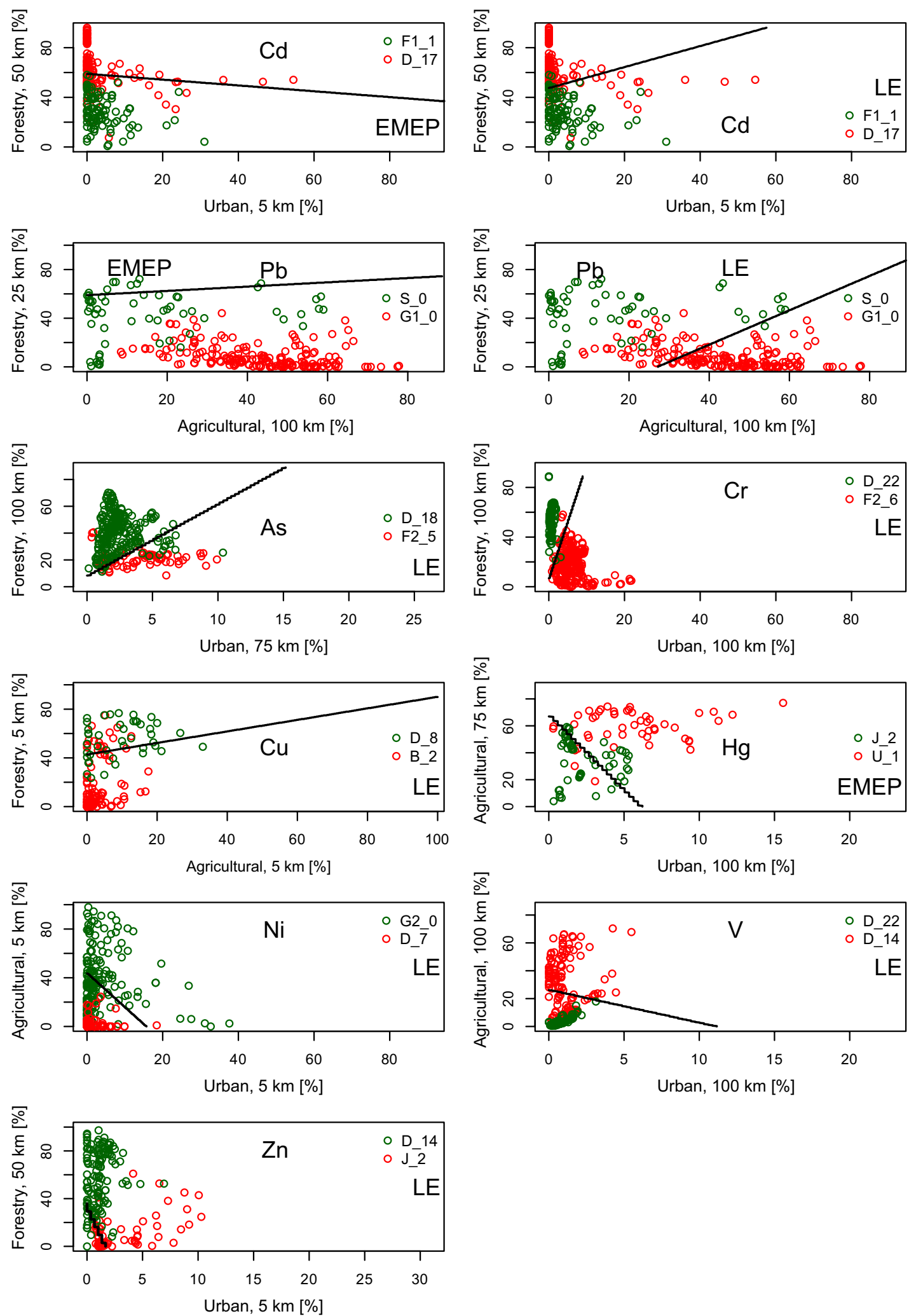

Fig. 4 Discriminant functions of LDA models for $\mathrm{As}, \mathrm{Cd}, \mathrm{Cr}, \mathrm{Cu}, \mathrm{Hg}, \mathrm{Ni}, \mathrm{Pb}, \mathrm{V}$, and $\mathrm{Zn}$. Discriminant functions (black lines) with relevant densities of land use around the sampling sites as predictors for separating between two ELCE revealing extremely high (= green) and low (= red) correlations selected as examples; atmospheric deposition was modelled by LE (2009-2011) or EMEP (2008-2010) 
Table 3 Error rates of LDA and LR models specified for nine heavy metals and two chemical transport models

\begin{tabular}{|c|c|c|c|c|c|c|c|c|c|c|c|}
\hline & EME & & & LOT & ROS & & & & & & \\
\hline & $\mathrm{Cd}$ & $\mathrm{Hg}$ & $\mathrm{Pb}$ & As & $\mathrm{Cd}$ & $\mathrm{Cr}$ & $\mathrm{Cu}$ & $\mathrm{Ni}$ & $\mathrm{Pb}$ & V & $\mathrm{Zn}$ \\
\hline LDA (\%) & 41 & 34 & 42 & 36 & 44 & 29 & 39 & 43 & 34 & 26 & 41 \\
\hline LR (\%) & 41 & 33 & 42 & 36 & 44 & 30 & 39 & 43 & 34 & 26 & 41 \\
\hline
\end{tabular}

Error rates of best models (<40\%) are in italic print; atmospheric deposition was modelled by LE (2009-2011) or EMEP (2008-2010)

Table 4 Correlations between heavy metal concentrations in moss and atmospheric deposition specified for ELCE categories and sampling site categories

\begin{tabular}{|c|c|c|c|c|c|c|c|c|c|c|c|c|c|}
\hline \multirow[t]{2}{*}{ Row ID } & \multirow[t]{2}{*}{ ELCE category } & \multirow[t]{2}{*}{ Site category } & \multicolumn{3}{|l|}{ EMEP } & \multicolumn{8}{|c|}{ LOTOS-EUROS } \\
\hline & & & $\mathrm{Cd}$ & $\mathrm{Hg}$ & $\mathrm{Pb}$ & As & $\mathrm{Cd}$ & $\mathrm{Cr}$ & $\mathrm{Cu}$ & $\mathrm{Ni}$ & $\mathrm{Pb}$ & V & $\mathrm{Zn}$ \\
\hline 1 & All & All & $0.65^{* *}$ & $0.14^{* *}$ & $0.70^{* *}$ & $0.30^{* *}$ & $0.65^{* *}$ & $0.03^{*}$ & $0.50^{* *}$ & $0.09 * *$ & $0.64^{* *}$ & $0.19 * *$ & $0.17^{* *}$ \\
\hline 2 & All & $A$ & $0.66^{* *}$ & $0.24^{* *}$ & $0.70^{* *}$ & $0.42^{* *}$ & $0.62^{* *}$ & $0.44^{* *}$ & $0.62^{* *}$ & $0.15^{* *}$ & $0.67^{* *}$ & $0.28^{* *}$ & $0.17^{* *}$ \\
\hline 3 & All & B & $0.41^{* *}$ & $-0.05^{* *}$ & $0.46^{* *}$ & $0.09 * *$ & $0.60^{* *}$ & $-0.29^{* *}$ & $0.40^{* *}$ & $-0.20^{* *}$ & $0.44^{* *}$ & 0.01 & -0.02 \\
\hline 4 & A & All & $0.75^{* *}$ & $0.22^{* *}$ & $0.72^{* *}$ & $0.45^{* *}$ & $0.72^{* *}$ & $0.22^{* *}$ & $0.50^{* *}$ & $0.16^{* *}$ & $0.67^{* *}$ & $0.21^{* *}$ & $0.22^{* *}$ \\
\hline 5 & $A$ & $A$ & $0.77^{* *}$ & $0.22^{* *}$ & $0.74^{* *}$ & $0.44^{* *}$ & $0.72^{* *}$ & $0.49^{* *}$ & $0.52^{* *}$ & $0.19^{* *}$ & $0.66^{* *}$ & $0.21^{* *}$ & $0.22 * *$ \\
\hline 6 & $A$ & $B$ & $0.26^{* *}$ & 0.17 & 0.28 & $0.35^{* *}$ & $0.45^{* *}$ & $-0.15^{* *}$ & $0.51^{* *}$ & $-0.08^{* *}$ & $0.60^{* *}$ & $0.14^{* *}$ & 0.06 \\
\hline 7 & $B$ & All & $0.50^{*}$ & 0.06 & $0.67^{* *}$ & $0.07^{* *}$ & $0.58^{* *}$ & $-0.26^{* *}$ & $0.45^{* *}$ & $-0.04^{* *}$ & $0.44^{* *}$ & $0.13^{* *}$ & $0.10 * *$ \\
\hline 8 & $B$ & A & $0.47^{* *}$ & $0.27^{* *}$ & $0.62^{* *}$ & $0.32^{* *}$ & $0.48^{* *}$ & $0.15^{* *}$ & $0.65^{* *}$ & $0.09^{* *}$ & $0.54^{* *}$ & $0.33^{* *}$ & $0.10^{* *}$ \\
\hline 9 & $B$ & B & $0.54^{* *}$ & $-0.18^{* *}$ & $0.55^{* *}$ & $-0.10^{* *}$ & $0.67^{* *}$ & $-0.36^{* *}$ & $0.27^{* *}$ & $-0.34^{* *}$ & $0.27^{* *}$ & -0.02 & -0.11 \\
\hline
\end{tabular}

ELCE category: $\mathrm{All}=\mathrm{ELCE}$ regions as a whole; $\mathrm{A}=\mathrm{ELCE}$ regions showing correlations above the element-specific class boundary between high and low correlation levels given in Table 2; $B=$ ELCE regions showing correlations below the element-specific class boundary between high and low correlation levels given in Table 2; site category: All = Moss sampling sites as a whole; $A=$ moss sampling sites classified by LDA model as $A ; B=$ moss sampling sites classified by LDA model as $B$; correlation coefficients according to Spearman; significant correlations are in italic print ( $\left.{ }^{*} p<0.05,{ }^{* *} p<0.01\right)$; atmospheric deposition was modelled by LE (2009-2011) or EMEP (2008-2010)

agricultural land use around the sampling sites should result in a higher and not in a lower correlation $(\mathrm{Ni})$, and discriminant lines between forestry and urban land use should in principal reveal a positive slope ( $\mathrm{Zn})$, as can be seen for $\mathrm{As}, \mathrm{Cr}, \mathrm{Cu}$, and $\mathrm{Pb}$. This may also explain the high error rates of $41-43 \%$ in case of $\mathrm{Ni}$ and $\mathrm{Zn}$.

Table 4 shows which LDA models are feasible for predicting correlation levels depending on land use around the sampling sites: The subset of A sites selected from the whole dataset by LDA (row 2) reveals increased correlation coefficients in case of $\mathrm{Hg}, \mathrm{As}, \mathrm{Cr}, \mathrm{Cu}$, and $\mathrm{V}$ compared to the European dataset, despite a smaller sampling size. Regarding the subsample of sites within ELCE regions showing above-average correlations (rows 4-6), sampling sites classified to B (row 6) reveal remarkably lower correlations for $\mathrm{Cd}, \mathrm{Pb}$, and $\mathrm{Cr}$, and sites classified to A (row 5) remarkably higher correlations for $\mathrm{Cr}$ compared to the whole partial sample (row 4). The same effect of increasing (row 8) and decreasing correlations (row 9) is visible also for the sampling sites within ELCE $B$ regions (rows 7-9) with respect to the LDA modelling results for $\mathrm{Hg}$, As, $\mathrm{Cr}, \mathrm{Cu}, \mathrm{Ni}, \mathrm{Pb}$, and $\mathrm{V}$.

Based on the study results described above, LDA models for $\mathrm{Pb}(\mathrm{LE}), \mathrm{As}, \mathrm{Cr}, \mathrm{Cu}, \mathrm{Hg}$, and $\mathrm{V}$ were selected as the most valid models further pursued for predictive mapping of correlations in "Predictive mapping of correlations" section.

\section{Predictive mapping of correlations}

The application of LDA models for $\mathrm{As}, \mathrm{Cr}, \mathrm{Cu}, \mathrm{Hg}, \mathrm{Pb}$ (LE), and $\mathrm{V}$ on the whole European dataset with information on density of land use around the sampling sites led to typical correlation patterns as depicted in Fig. 5 . While northern Europe and the Alps are predominately characterized by correlations above the average, the other regions frequently reveal low correlation levels. Further correlation patterns for the remaining element are presented in Additional file 1: Figure S2.

An aggregated view on LDA predictions for $\mathrm{As}, \mathrm{Cr}, \mathrm{Cu}$, $\mathrm{Hg}, \mathrm{Pb}$, and $\mathrm{V}$ feasible within countries supplying sufficient information on LDA predictors with blanket coverage derived from CLC 2006 is shown in Fig. 6.

Areas with 5-6 out of 6 LDA models revealing potential high correlations are located in Fennoscandia, Scotland, Austria and parts of the Baltics, South-eastern Europe, Turkey, France, and Spain $(=20 \%$ of the area covered with spatial information on land use density around $10 \mathrm{~km} \times 10 \mathrm{~km}$ grids). Information about the elements being relevant at specific locations is given in Fig. 5. Countries comprising regions with consistently 


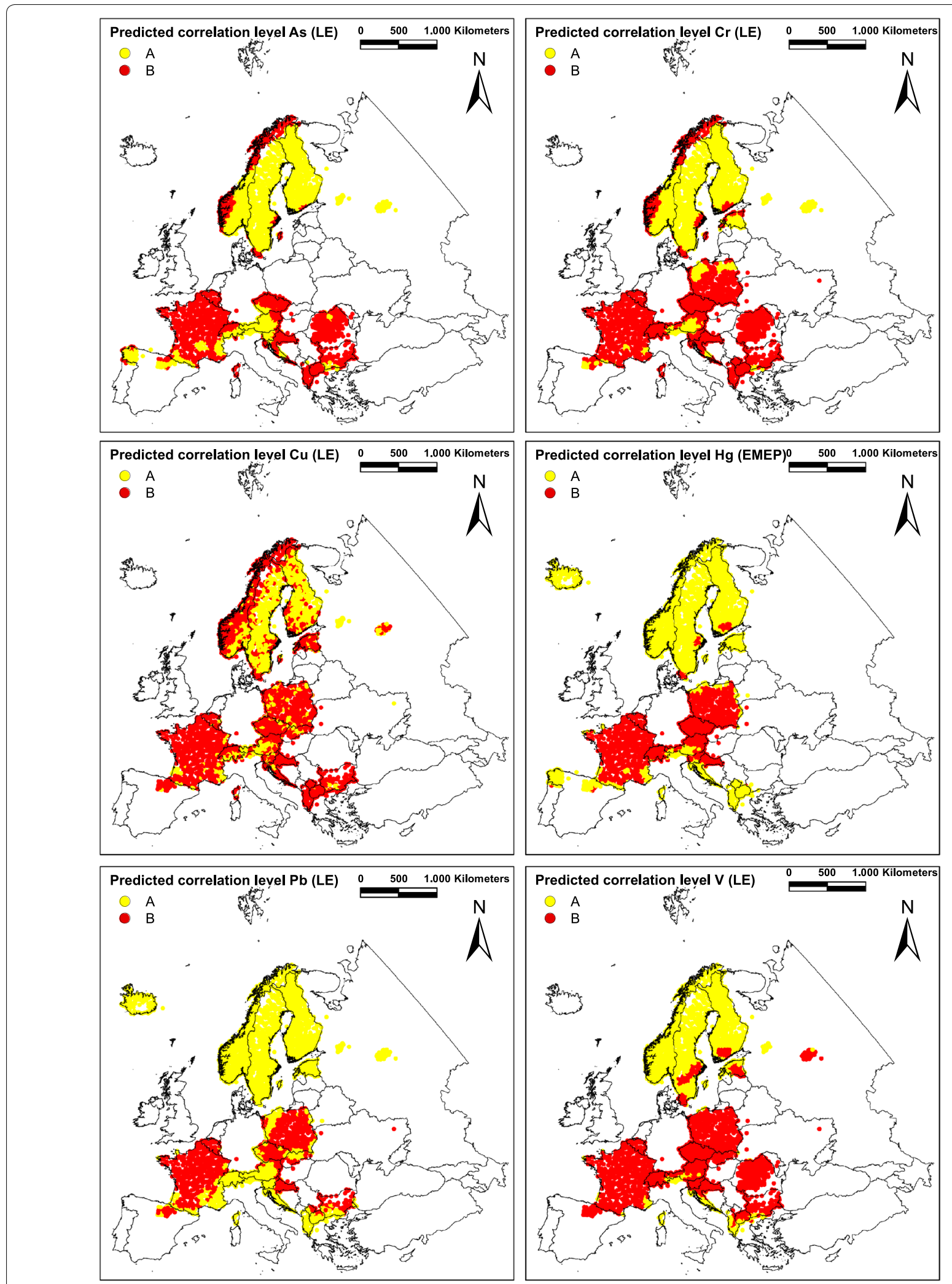

Fig. 5 Predicted correlation patterns for $\mathrm{As}, \mathrm{Cr}, \mathrm{Cu}, \mathrm{Hg}, \mathrm{Pb}$, and $\mathrm{V}$ (moss; EMEP/LE) at site level as classified according to their surrounding land use with above element-specific average (=A) or below-average (=B) correlations (cf. Table 2) 


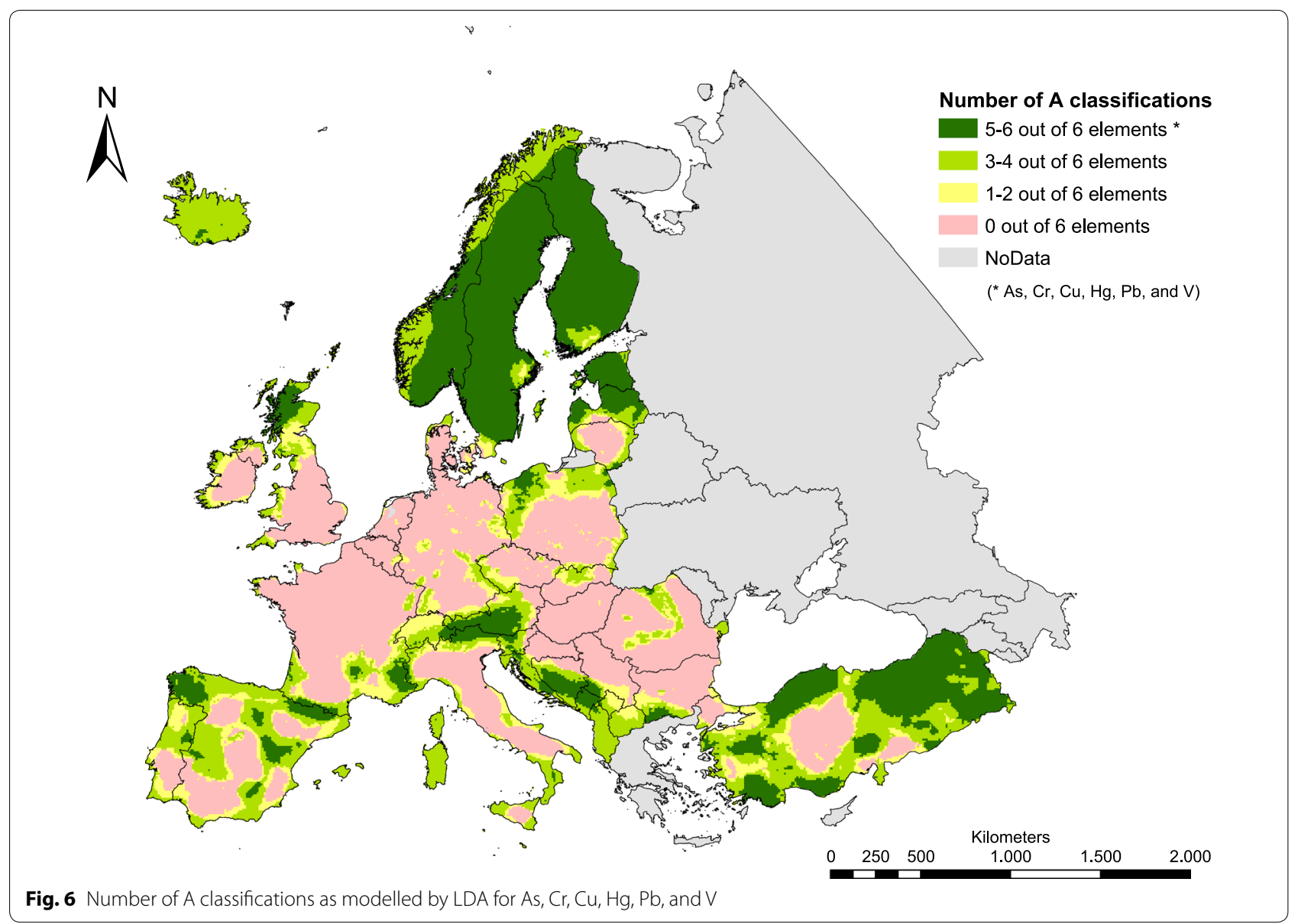

low potential correlations ( 0 out of 6 classifications to A) can be in particular found in western, Central and Southeastern Europe ( $=38 \%$ of the area being investigated). The remaining area $(42 \%)$ is characterized by locations where correlation levels for 1-4 out of 6 elements were classified to A.

\section{Discussion}

\section{Correlation analysis}

For all investigated $\mathrm{HM}(\mathrm{As}, \mathrm{Cd}, \mathrm{Cr}, \mathrm{Cu}, \mathrm{Hg}, \mathrm{Ni}, \mathrm{Pb}, \mathrm{V}$, and $\mathrm{Zn}$ ), the correlations between concentrations in moss and the modelled total atmospheric deposition (EMEP, LOTOS-EUROS) were land class specific and element specific. Significant positive correlations were found for about 30\% (As), 78-81\% (Cd), 15\% (Cr), 63\% $(\mathrm{Cu}), 44 \%(\mathrm{Hg}), 15 \%(\mathrm{Ni}), 78-89 \%(\mathrm{~Pb}), 19 \%(\mathrm{~V})$, and $44 \%$ (Zn) of 27 ELCE units being represented by moss sample sizes $n>10$. This is in line with similar findings for $\mathrm{Cd}, \mathrm{Hg}$ and $\mathrm{Pb}$ based on data from $2005[9,10]$ and was supplemented for further seven elements. This study confirms that mosses are good biomonitors for atmospheric deposition of $\mathrm{Cd}$ and $\mathrm{Pb}$ [38] and to some extent also for $\mathrm{Cu}$, but this study suggests that mosses are less good as biomonitors for other $\mathrm{HM}$ like $\mathrm{Cr}, \mathrm{Hg}, \mathrm{Ni}, \mathrm{V}$, and $\mathrm{Zn}$. The amount of ELCE-specific correlation coefficients is closely connected to uncertainties in deposition modelling contributing to variation and potential influencing factors in the use of mosses as monitors of atmospheric deposition [38, 39]. Particular mention is to be made of different emission data used for EMEP and LE [40] probably explaining the differences in the correlations (Table 2) and, respectively, the direction and/or intensity of the discriminant lines $(\mathrm{Cd}$ and $\mathrm{Pb}$ in Fig. 4). Besides this, modelled data are grid-specific (LE: $25 \mathrm{~km} \times 25 \mathrm{~km}$; EMEP: $50 \mathrm{~km} \times 50 \mathrm{~km}$ ) and moss data are site specific, meaning that we are always working at spatial limits of extrapolation in the moss monitoring network. Density of land use around the sampling sites should not only considered as a relevant factor for element concentrations in moss [12, 13], but even more as an indicator for influencing factors such as areal and point emission sources that are very evident in some Balkan countries effected mainly from windblowing dust and mineral particles [41-43]. Further important factors than those 
considered in the modelling of background atmospheric deposition influencing the amount of correlation are particularly mineral particles, mainly windblown dust from local soil (As, $\mathrm{Cd}, \mathrm{Cr}, \mathrm{Cu}, \mathrm{Hg}, \mathrm{Ni}, \mathrm{V}$ ) and root uptake in higher plants from soil and transfer to mosses by leaching from dead or living plant material [44]. Low correlations with As implies that As metabolism could be more involved than expected [45]. Also precipitation $\mathrm{pH}$ may play a role because it affects the solubility of heavy metals and hence their uptake by mosses which should be taken into account in further investigations. Due to the existing uncertainties in the deposition modelling, future studies should also include comparisons between heavy metal concentrations in moss tissue and atmospheric deposition measured by technical samplers, e.g. within the EMEP framework [22]. Also, other potential pollutants, such as nitrogen or persistent organic pollutants (POP), should be included. First pilot studies on POP exist, for example, in Germany [5].

\section{Statistical modelling}

The use of LDA enables a separation of moss sampling sites regarding their contribution to the correlation level in dependency on urban, agricultural and forestry land use around the sampling location. LDA and LR help explaining spatial patterns of ELCE-specific correlation levels by identifying most relevant land uses and radiuses around the sampling sites. A very valuable indicator for this was that moss sampling sites classified by LDA as A within ELCE B units defined by below element-specific average correlations show stronger correlations than the whole set of sampling sites within ELCE B units ( $\mathrm{Hg}$, As, $\mathrm{Cr}, \mathrm{Cu}, \mathrm{Pb}, \mathrm{V})$. Vice versa, category B sites from ELCE A units reveal lower correlations than the whole subsample from ELCE A units (As, $\mathrm{Cd}, \mathrm{Pb}, \mathrm{Cr}, \mathrm{Ni}$ ). This means that the ELCE-specific correlation levels are more strongly dependent on land use within the specified radii around the sampling sites and less on the spatial assignment to specific ELCE units, which per se have high or low correlations. For example: Each random subsample within regions showing low correlations between $\mathrm{Hg}$ concentrations in moss and respective atmospheric deposition is expected to reveal low correlations. If LDA selects a subsample indicating high correlations within regions showing low correlations, the importance of the predictors for $\mathrm{Hg}$ can be graded as high. Best LDA models with error rates $<40 \%$ were found for $\mathrm{As}, \mathrm{Cr}, \mathrm{Cu}, \mathrm{Hg}, \mathrm{Pb}$, and V. Similar error rates were found by means of LR, confirming the validity of LDA models, which are more graphic and less difficult to interpret. This supports our approach to use LDA in conjunction with a confirmation by LR, which is in any case recommended for multivariate statistics, especially since predictors are not normally distributed. Likewise, relevant factors for predicting potential correlation levels are element specific. While density of forestry land use might characterize a seclusion of sampling locations, urban and agricultural land use around the sampling sites might indicate pronounced influences of local emission sources. For $\mathrm{Cd}, \mathrm{Cu}$, and $\mathrm{Ni}$, small radiuses are relevant. For $\mathrm{Cd}$ and $\mathrm{Cu}$, the relevance of agricultural land use within a small range of 0-5 $\mathrm{km}$ could be caused by fertilizers $(\mathrm{Cd})$ and coppercontaining pesticides [46]. For $\mathrm{Cd}$ and $\mathrm{Ni}$, the relevance of urban land use within a radius of $5 \mathrm{~km}$ might be connected to local industrial emission sources. By contrast, large radiuses of 75-100 km are most relevant for As, $\mathrm{Hg}$, $\mathrm{Cr}$ and $\mathrm{V}$, which predominantly show the weakest statistical relations to modelled atmospheric deposition. At least for $\mathrm{Hg}$, this could be a result of long residence times of $\mathrm{Hg}$ components in the atmosphere and correlated longrange transport $[47,48]$. Regarding As and $\mathrm{Cr}$, high density of forestry land use within a $100 \mathrm{~km}$ radius, which might indicate a low influence of local emission sources, seems to be a crucial factor. Regarding $\mathrm{As}, \mathrm{Hg}, \mathrm{Cr}$ and $\mathrm{V}$, this study indicates that the radius for examining the influence of different spatial land use density around the sampling sites could be even more enlarged (e.g. 150, 200 or $250 \mathrm{~km}$ ) for a probably better consideration of the long-range transboundary air pollution.

\section{Predictive mapping}

LDA modelling in combination with LR is an eligible method for predicting and mapping spatial patterns of correlations in dependency of the influence of the environmental factors. Based on error rates and spatial patterns analysis, the explanatory power of 6 out of 11 LDA models with error rates $<40 \%$ (As, $\mathrm{Cr}, \mathrm{Cu}, \mathrm{Hg}, \mathrm{Pb}$, and $\mathrm{V})$ was found to be sufficient. However, error rates of $26-39 \%$ imply strong influences of other factors, i.e. the predictions are connected with high uncertainties and should be regarded as indications only.

\section{Conclusions}

The predictive mapping provides spatial indication on the presence of other factors for element concentration in moss than those considered in the modelling of background atmospheric deposition, e.g. local emission sources or mineral windblown dust from soil [44]. The LDA discriminants could be, at least on the large scale, used as additional criteria for planning moss survey networks beyond the recommendations of the Moss Manual such as minimum distances from roads or houses [19]. Besides, the classification and selection of sampling sites can serve as a preliminary stage for detailed site-specific investigations of possible local factors. To this end, binary classification (A, B) of the LDA models should be 
refined, in order to increase the spatial differentiation in particular for countries revealing low predicted correlation levels (e.g. Belgium, northern France). The predicted correlation level could then be integrated into more comprehensive sets of criteria for planning (reductions of existing) moss survey networks [49]. Predictive maps could also be useful for initial estimations of the correlation level in regions beyond the EMS network having sufficient information on land use with blanket coverage (e.g. Estonia, Kosovo, parts of Spain or Turkey). The underlying assumption is that land use around potential sampling sites in countries that did not submit data for 2010 EMS affects the correlation on the same order of magnitude as in countries that participate in EMS. For decision support, it is recommended to aggregate models results to reduce complexity. LDA models and predictive mapping should be validated with further independent data from the EMS 1990, 1995, 2000, 2005, and 2015.

\section{Additional file}

Additional file 1: Figure S1. Map of Ecological Land Classes of Europe [15]. Table S1. Legend of the map on Ecological Land Classes of Europe [15]. Table S2. Description of Chemical Transport Models (CTM) used as data source. Figure $\mathbf{S 2}$. Predicted correlation patterns for $\mathrm{Cd}, \mathrm{Ni}, \mathrm{Pb}$, and Zn (moss; EMEP/LE) at site level as classified according to their surrounding land use with above element-specific average $(=A)$ or below e.-s. average $(=\mathrm{B})$ correlations.

\section{Abbreviations}

As: arsenic; B_1: western and northern Scandinavia, Northwest Russia; B_2: the Alps, Iceland, Northwest Russia; C_0: the Alps, Iceland, western and northern Scandinavia, Kola Peninsula, Northwest Russia, Caucasus; Cd: cadmium; CLRTAP: convention on long-range transboundary air pollution; $\mathrm{Cr}$ : chromium; CTM: chemical transport model; Cu: copper; D_10: Russia; D_13: the Alps, dispersed small areas in eastern and Southeast Europe; D_14: Baltic states, Belarus, western Russia; D_16: Northeast European hygrophilous spruce forests with dwarf scrubs, sedges and mosses; D_17: Scandinavia, western Russia; D_18: southern Scandinavia, northern Baltic states; D_19: southern/ central Finland, Norway; D_21: Northwest Russia; D_22: Sweden, Northwest Russia; D_7: Scandinavia, Northwest Russia; D_8: Kola Peninsula, Northwest Russia; ELCE: ecological land classes of Europe; EMEP: European monitoring and evaluation programme; EMS: European Moss Survey; F1_1: Poland, Northwest Ukraine; F1_2: Ireland, Great Britain, western and central Europe; F2 5: southern Baltic states, eastern Poland, western and Southwest Ukraine; F2_6: central Europe, eastern and Southeast Europe; F3_1: Germany, Northwest Poland, Czech Republic, northern Austria, Slovenia, the Balkans; F3_2: western Europe (including northern Spain, France, Benelux countries, western Germany), Denmark; F4_1: Southeast Great Britain, Southeast Denmark, Northeast Germany, Northwest Poland; F4_2: western/central and southern Europe (including southern Great Britain, eastern France, southern Belgium, Luxembourg, the Alps, Italy), eastern and Southeast Europe (including the Carpathian Mountains, the Balkans); G1_0: Italy, Southeast Europe; G2_0: Iberian Peninsula, southern and Southeast Europe; Hg: Mercury; HM: heavy metals; ICP: international cooperative programme; J_2: Iberian Peninsula, coastal areas by the Mediterranean Sea; L_2: eastern Europe (Hungary, Romania, Moldova, Ukraine, Russia); LDA: linear discriminant analysis; LE: LOTOS-EUROS; LR: logistic Regression; M_5: eastern Ukraine, Southwest Russia, Caukasus; M_6: eastern Romania, southern Ukraine; MSC-E: meteorological synthesizing centres MSC-East (Moscow); N: nitrogen; Ni: nickel; Pb: lead; POP: persistent organic pollutants; $r_{s}$ : correlation coefficient (Spearman); S_0: northern parts of Europe (including parts of Iceland, Ireland, Great Britain, Scandinavia, Northwest Russia, the Blatic states and Belarus); U_1: dispersed small areas within a stripe reaching from Ireland via central Europe and the Byelorussian-Ukrainian borderline to Russia; U_2: dispersed small areas in southern Europe reaching from the Iberian Peninsula via Southeast Europe including, e.g. the Balkans, the Carpathians, Greece and northern Turkey to Southwest Russia; UN-ECE: United Nations Economic Commission for Europe; V: vanadium; Zn: zinc.

\section{Authors' contributions}

The participants of the European Moss Survey supplied the moss data and the ICP Vegetation Programme Coordination Centre processed the data. WS headed the computations executed by SN, RS and MS. SN and WS wrote the article. All authors commented on the draft manuscript. All authors read and approved the final manuscript.

\section{Author details}

${ }^{1}$ Chair of Landscape Ecology, University of Vechta, Vechta, Germany. ${ }^{2}$ ICP Vegetation Programme Coordination Centre, Centre for Ecology and Hydrology, Bangor, Gwynedd LL57 2UW, UK. ${ }^{3}$ Moss Survey Coordination Centre, Frank Laboratory of Neutron Physics, Dubna, Moscow Region, Russian Federation. ${ }^{4}$ Ss. Cyril and Methodius University, Skopje, Macedonia. ${ }^{5}$ National Botanical Garden, Academy of Science of Ukraine, Kiev, Ukraine. ${ }^{6}$ University of Santiago de Compostela, Santiago de Compostela, Spain. ${ }^{7}$ Sciensano, Tervuren, Belgium. ${ }^{8}$ Ivanovo State University of Chemistry and Technology, Ivanovo, Russia. ${ }^{9}$ Dunarea de Jos University of Galati, Galati, Romania. ${ }^{10}$ Norwegian Meteorological Institute, Oslo, Norway. ${ }^{11}$ W. Szafer Institute of Botany, Polish Academy of Sciences, Kraków, Poland. ${ }^{12}$ Meteorological Synthesizing Centre East, Moscow, Russia. ${ }^{13}$ TNO, Utrecht, The Netherlands. ${ }^{14}$ Jožef Stefan Institute, Ljubljana, Slovenia. ${ }^{15}$ University of Tirana, Tirana, Albania. ${ }^{16}$ National Museum of Natural History, Paris, France. ${ }^{17}$ Tallinn Botanic Garden, Tallinn, Estonia. ${ }^{18}$ Institute of Landscape Ecology, Slovak Academy of Sciences, Bratislava, Slovak Republic. ${ }^{19}$ University of La Rioja, Logroño, Spain. ${ }^{20}$ Natural Resources Institute Finland (Luke), Oulu, Finland. ${ }^{21}$ Valahia University of Targoviste, Targoviste, Romania. ${ }^{22}$ University of Vlora, Vlorë, Albania. ${ }^{23}$ University of Navarra, Navarra, Spain. ${ }^{24}$ Slovenian Forestry Institute, Ljubljana, Slovenia. ${ }^{25}$ Green Infrastructure Ltd., Zagreb, Croatia. ${ }^{26}$ Norwegian University of Science and Technology, Trondheim, Norway. ${ }^{27}$ Silva Tarouca Research Institute for Landscape and Ornamental Gardening, Průhonice, Czech Republic.

${ }^{28}$ Norwegian Institute for Air Research, Kjeller, Norway. ${ }^{29}$ University of Vienna, Vienna, Austria.

\section{Acknowledgements}

This research paper was only possible through the help and support of the Federal Environmental Agency, Dessau-Roßlau, Germany, the Meteorological Synthesizing Centre-East (MSC-E), Moscow, Russia, and the ICP Vegetation Programme Coordination Centre, Centre for Ecology \& Hydrology, Bangor, UK.

\section{Competing interests}

The authors declare that they have no competing interests.

\section{Availability of data and materials}

The datasets generated and/or analysed during the current study are not publicly available due to copyright but are available from the corresponding author on reasonable request.

\section{Consent for publication}

Not applicable.

\section{Ethics approval and consent to participate}

Not applicable.

\section{Funding}

We thank the United Kingdom Department for Environment, Food and Rural Affairs (Defra; contract AQ0810, AQ0833 and AQ0846), the UNECE (Trust Fund) and the Natural Environment Research Council (NERC) for funding the ICP Vegetation Programme Coordination Centre.

\section{Publisher's Note}

Springer Nature remains neutral with regard to jurisdictional claims in published maps and institutional affiliations. 
Received: 18 October 2018 Accepted: 11 December 2018 Published online: 21 December 2018

\section{References}

1. Tørseth K, Aas W, Breivik K, Fjæraa AM, Fiebig M, Hjellbrekke AG, Lund Myhre C, Solberg S, Yttri KE (2012) Introduction to the European monitoring and evaluation programme (EMEP) and observed atmospheric composition change during 1972 and 2009. Atmos Chem Phys 12:5447-5481

2. Frontasyeva MV, Steinnes E, Harmens H (2016) Monitoring long-term and large-scale deposition of air pollutants based on moss analysis. In: Aničić Urošević M, Vuković G, Tomašević M (eds) Biomonitoring of air pollution using mosses and lichens Passive and active approach — state of the art and perspectives. Air, water and soil pollution science and technology. Nova Science Publishers, Hauppauge, pp 1-20

3. Harmens H, Mills G, Hayes F, Norris DA, Sharps K (2015) Twenty-eight years of ICP vegetation: an overview of its activities. Ann Bot 5:31-43

4. Harmens H, Norris DA, Sharps K, Mills G, Alber R, Aleksiayenak Y, Blum O, Cucu-Man S-M, Dam M, De Temmerman L, Ene A, Fernández JA, Martinez-Abaigar J, Frontasyeva M, Godzik B, Jeran Z, Lazo P, Leblond S, Liiv S, Magnússon SH, Maňkovská B, Pihl Karlsson G, Piispanen J, Poikolainen J, Santamaria JM, Skudnik M, Spiric Z, Stafilov T, Steinnes E, Stihi C, Suchara I, Thöni L, Todoran R, Yurukova L, Zechmeister HG (2015) Heavy metal and nitrogen concentrations in mosses are declining across Europe whilst some "hotspots" remain in 2010. Environ Pollut 200:93-104

5. Dreyer A, Nickel S, Schröder W (2018) (Persistent) Organic pollutants in Germany: results from a pilot study within the 2015 moss survey. Environ Sci Eur 30(43):1-14. https://doi.org/10.1186/s12302-018-0172-y

6. Holy M, Schröder W, Pesch R, Harmens H, Ilyin I, Steinnes E, Alber R, Aleksiayenak Y, Blum O, Coskun M, Dam M, De Temmerman L, Frolova M, Frontasyeva M, Gonzalez Miqueo L, Grodzinska K, Jeran Z, Korzekwa S, Krmar M, Kubin E, Kvietkus K, Leblond S, Liiv S, Magnusson S, Mankovska B, Piispanen J, Rühling Å, Santamaria J, Spiric Z, Suchara I, Thöni L, Urumov V, Yurukova L, Zechmeister HG (2010) First thorough identification of factors associated with $\mathrm{Cd}, \mathrm{Hg}$ and $\mathrm{Pb}$ concentrations in mosses sampled in the European Surveys 1990, 1995, 2000, and 2005. J Atmos Chem 63:109-124

7. Schröder W, Holy M, Pesch R, Harmens H, Fagerli H, Alber R, Coşkun M, De Temmerman L, Frolova M, González-Miqueo L, Jeran Z, Kubin E, Leblond S, Liiv S, Maňkovská B, Piispanen J, Santamaría JM, Simonèiè P, Suchara I, Yurukova L, Thöni L, Zechmeister HG (2010) First europe-wide correlation analysis identifying factors best explaining the total nitrogen concentration in mosses. Atmos Environ 4:3485-3491

8. Schröder W, Holy M, Pesch R, Harmens H, Ilyin I, Steinnes E, Alber R, Aleksiayenak Y, Blum O, Coskun M, Dam M, De Temmerman L, Frolova M, Frontasyeva M, Gonzalez Miqueo L, Grodzinska K, Jeran Z, Korzekwa S, Krmar M, Kubin E, Kvietkus K, Leblond S, Liiv S, Magnusson S, Mankovska B, Piispanen J, Rühling Å, Santamaria J, Spiric Z, Suchara I, Thöni L, Urumov V, Yurukova L, Zechmeister HG (2010) Are cadmium, lead and mercury concentrations in mosses across Europe primarily determined by atmospheric deposition of these metals? J Soils Sediments 10:1572-1584

9. Harmens H, Ilyin I, Mills G, Aboal JR, Alber R, Blum O, Coskun M, De Temmerman L, Fernandez JA, Figuera R, Frontasyeva M, Godzik B, Goltsova N, Jeran Z, Korzekwa S, Kubin E, Kvietkus K, Leblond S, Liiv S, Magnusson SH, Mankovska B, Nikodemus O, Pesch R, Poikolainen J, Radnovic D, Rühling A, Santamaria JM, Schröder W, Spiric Z, Stafilov T, Steinnes E, Suchara I, Tabors G, Thöni L, Turcsanyi G, Yurukova L, Zechmeister HG (2012) Country-specific correlations across Europe between modelled atmospheric cadmium and lead deposition and concentration in mosses. Environ Pollut 166:1-9

10. Schröder W, Pesch R, Hertel A, Schönrock S, Harmens H, Mills G, Ilyin I (2013) Correlation between atmospheric deposition of $\mathrm{Cd}, \mathrm{Hg}$ and $\mathrm{Pb}$ and their concentrations in mosses specified for ecological land classes covering Europe. Atmos Pollut Res 4:267-274

11. Travnikov O, Ilyin I (2005) Regional model MSCE-HM of heavy metal transboundary air pollution in Europe. EMEP/MSC-E technical report 6/2005, p 59

12. Meyer M, Schröder W, Pesch R, Steinnes E, Uggerud HT (2015) Multivariate association of regional factors with heavy metal concentrations in moss and natural surface soil sampled across Norway between 1990 and 2010. J Soils Sediments 15:410-422
13. Nickel S, Hertel A, Pesch R, Schröder W, Steinnes E, Uggerud HT (2014) Modelling and mapping spatio-temporal trends of heavy metal accumulation in moss and natural surface soil monitored 1990-2010 throughout Norway by multivariate generalized linear models and geostatistics. Atmos Environ 99:85-93

14. Skudnik M, Jeran Z, Batič F, Simončič P, Kastelec D (2015) Potential environmental factors that influence the nitrogen concentration and $815 \mathrm{~N}$ values in the moss Hypnum cupressiforme collected inside and outside canopy drip lines. Environ Pollut 198:78-85

15. Hornsmann I, Pesch R, Schmidt G, Schröder W (2008) Calculation of an ecological land classification of Europe (ELCE) and its application for optimising environmental monitoring networks. In: Car A, Griesebner G, Strobl J (eds). Geospatial Crossroads @ Gl_Forum '08: proceedings of the Geoinformatics Forum Salzburg. Wichmann, Heidelberg, pp 140-151

16. Schaap M, Sauter F, Timmermans RMA, Roemer M, Velders G, Beck J, Builjes PJH (2008) The LOTOS-EUROS model: description, validation and latest developments. Int J Environ Pollut 32(2):270-290

17. EEA (2016) Corine Land Cover 2006 (CLC 2006). Available via DIALOG. http://www.eea.europa.eu/data-and-maps/data/corine-land-cover-2006raster-2. Accessed 09 Feb 2016

18. EEA (2016) Global Land Cover 2000_Europe (GLC 2000). Available via DIALOG. http://www.eea.europa.eu/data-and-maps/data/global-landcover-2000-europe. Accessed 09 Feb 2016

19. ICP Vegetation (2010) Heavy metals in European Mosses: 2010 survey. Monitoring manual, international cooperative programme on effects od air pollution on natural vegetation and crops, ICP Coordination Centre, CEH Bangor, pp 1-16. http://nora.nerc.ac.uk/id/eprint/9952/1/UNECE HEAVYMETALSMOSSMANUAL2010POPsadaptedfinal_220510_.pdf. Accessed 23 Nov 2018

20. Hill MO, Bell N, Bruggeman-Nannenga MA, Brugués M, Cano MJ, Enroth J, Flatberg KI, Frahm J-P, Gallego MT, Garilleti R, Guerra J, Hedenäs L, Holyoak DT, Hyvönen J, Ignatov MS, Lara F, Mazimpaka V, Muñoz J, Söderström L (2006) An annotated checklist of the mosses of Europe and Macaronesia. J Bryol 28:198-267

21. Builtjes P, Schaap M, Jonkers S, Nagel HD, Nickel S, Schlutow A, Schröder W (2017) Impacts of heavy metal emissions on air quality and ecosystems in Germany (part 1). Final report on behalf of the German Federal Environmental Agency, Dessau-Roßlau, p 81

22. Aas W, Breivik K (2009) Heavy metals and POP measurements 2007. EMEP/CCC-report 3/2009. Norwegian Institute for Air Research, Kjeller, Norway. https://www.nilu.no/projects/ccc/reports/cccr3-2009.pdf. Accessed 23 Nov 2018

23. Bohn U, Hettwer C, Gollub G (eds) (2005) Application and analysis of the map of the natural vegetation of Europe, vol 156. Bonn, BfN-Skripten (Bundesamt fur Naturschutz), p 452

24. Hastings DA, Dunbar PK, Elphingstone GM, Bootz M, Murakami H, Maruyama H, Masaharu H, Holland P, Payne J, Bryant NA, Logan TL, Muller JP, Schreier G, Macdonald JS (1999) The global land one-kilometer base elevation (GLOBE) digital elevation model version 1.0., National Oceanic and Atmospheric Administration, National Geophysical Data Center, USA https://www.ngdc.noaa.gov/mgg/topo/report/globedocumentationma nual.pdf. Accessed 23 Nov 2018

25. FAO (Food and Agriculture Organization of the United Nations)/IIASA (International Institute of Applied Systems Analysis)/ISRIC-World Soil Information/ISS-CAS (Institute of Soil Science, Chinese Academy of Science)/JRC (Joint Research Centre of the European Commission) (2009) Harmonized World Soil Database (version 1.1). Italy and IIASA, Laxenburg, Austria, FAO, Rome. http://www.fao.org/3/a-aq361e.pdf. Accessed 23 Nov 2018

26. New M, Lister D, Hulme M, Makin I (2002) A high-resolution data set of surface climate over global land areas. Climate Res 21:1-25

27. Breiman L, Friedman J, Olshen R, Stone C (1984) Classification and regression trees. Wadsworth, Belmont

28. Schröder W, Nickel S, Schönrock S, Schmalfuß R, Wosniok W, Meyer M Harmens H, Frontasyeva MV, Alber R, Aleksiayenak J, Barandovski L, Blum O, Carballeira A, Dam M, Danielsson H, de Temmermann L, Dunaev AM, Godzik B, Hoydal K, Jeran Z, Pihl Karlsson G, Lazo P, Leblond S, Lindroos J, Liiv S, Magnússon SH, Mankovska B, Núñez-Olivera E, Piispanen J, Poikolainen J, Popescu IV, Qarri F, Santamaria JM, Skudnik M, Špiric Z, Stafilov T, Steinnes E, Stihi C, Suchara I, Thöni L, Uggerud HT, Zechmeister HG (2017) Bioindication and modelling of atmospheric deposition in forests 
enable exposure and effect monitoring at high spatial density across scales. Ann For Sci 74(31):1-23

29. Schröder W, Nickel S, Schönrock S, Meyer M, Wosniok W, Harmens H, Frontasyeva MV, Alber R, Aleksiayenak J, Barandovski L, Danielsson H, de Temmermann L, Fernández Escribano A, Godzik B, Jeran Z, Pihl Karlsson G, Lazo P, Leblond S, Lindroos A-J, Liiv S, Magnússon SH, Mankovska B, Martínez-Abaigar J, Piispanen J, Poikolainen J, Popescu IV, Qarri F, Santamaria JM, Skudnik M, Špiric Z, Stafilov T, Steinnes E, Stihi C, Thöni L, Uggerud HT, Zechmeister HG (2016) Spatially valid data of atmospheric deposition of heavy metals and nitrogen derived by moss surveys for pollution risk assessments of ecosystems. Environ Sci Pollut Res 23:10457-10476

30. Brosius F (2013) SPSS 21. Mitp/bhv, Heidelberg, p 1054

31. Backhaus K, Erichson B, Plinke W, Weiber R (2011) Multivariate Analysemethoden. Eine anwendungsorientierte Einführung, 13, überarb. Aufl., Springer, Berlin

32. Fisher RA (1936) The use of multiple measurements in taxonomic problems. Ann Eugen 7(2):179-188

33. Varmuza K, Filzmoser P (2008) Introduction to multivariate statistical analysis in chemometrics. CRC Press, Taylor \& Francis, Boca Raton, p 321

34. Nickel S, Schröder W, Wosniok W, Harmens H, Frontasyeva MV, Alber R, Aleksiayenak J, Barandovski L, Blum O, Danielsson H, de Temmermann L, Dunaev A, Fagerli H, Godzik B, lliyn I, Jonkers S, Jeran Z, Pihl Karlsson G, Lazo P, Leblond S, Liiv S, Magnússon SH, Mankovska B, Martínez-Abaigar J, Piispanen J, Poikolainen J, Popescu IV, Qarri F, Radnovic D, Santamaria JM, Schaap M, Skudnik M, Špiric Z, Stafilov T, Steinnes E, Stihi C, Suchara I, Thöni L, Uggerud HT, Zechmeister HG (2017) Modelling and mapping heavy metal and nitrogen concentrations in moss in 2010 throughout Europe by applying random forests models. Atmos Environ 156:146-159

35. Schönwiese CD (2000) Praktische Statistik für Meteorologen und Geowissenschaftler. Gebrüder Borntraeger Verlag, Berlin, p 298

36. R Core Team (2013) R: a language and environment for statistical computing. R Foundation for Statistical Computing. Vienna. http://www.R-proje ct.org/. Accessed 19 June 2017

37. Venables WN, Ripley BD (2002) Modern applied statistics with S, 4th edn. Springer, New York
38. Aboal JR, Fernandez JA, Boquete T, Carballeira A (2010) Is it possible to estimate atmospheric deposition of heavy metals by analysis of terrestrial mosses? Sci Total Environ 40:6291-6297

39. Harmens H, Norris DA, Koerber GR, Buse A, Steinnes E, Rühling A (2008) Temporal trends (1990-2000) in the concentration of cadmium, lead and mercury in mosses across Europe. Environ Pollut 151:368-376

40. Nickel S, Schröder W (2017) Integrative evaluation of data derived from biomonitoring and models indicating atmospheric deposition of heavy metals. Environ Sci Pollut Res 24:11919-11939

41. Barandovski L, Frontasyeva VM, Stafilov T, Šajn R, Ostrovnaya MT (2015) Multielement atmospheric deposition in Macedonia studied by the moss biomonitoring technique. Environ Sci Pollut Res 22:16077-16097

42. Qarri F, Lazo P, Stafilov T, Frontasyeva M, Harmens H, Bekteshi L, Baceva K, Goryainova Z (2014) Multi-elements atmospheric deposition study in Albania. Environ Sci Pollut Res 21:2506-2518

43. Špirić Z, Frontasyeva VM, Stafilov T (2012) Multi-element atmospheric deposition study in Croatia. Int J Environ Anal Chem 92(10):1402-1408

44. Steinnes $E$ (1995) A critical evaluation of the use of naturally growing moss to monitor the deposition of atmospheric metals. Sci Total Environ 160(161):243-249

45. Meharg AA, Hartley-Whitaker J (2002) Arsenic uptake and metabolism in arsenic resistant and nonresistant plant species. New Phytol 154(1):29-43

46. Husak VV (2015) Copper and copper-containing pesticides: metabolism, toxicity and oxidative stress. J Vasyl Stefanyk Precarpathian Natl Univ 2:39-51

47. Berg T, Fjeld E, Steinnes E (2006) Atmospheric mercury in Norway: contributions from different sources. Sci Total Environ 368(1):3-9

48. Lindqvist O, Rodhe H (1985) Atmospheric mercury—a review. Tellus B 37B:136-159

49. Nickel S, Schröder W (2017) Reorganisation of a long-term monitoring network using moss as bioindicator for atmospheric deposition in Germany. Ecological Indic 76:194-206

\section{Submit your manuscript to a SpringerOpen ${ }^{\odot}$ journal and benefit from:}

- Convenient online submission

- Rigorous peer review

- Open access: articles freely available online

- High visibility within the field

- Retaining the copyright to your article

Submit your next manuscript at $\boldsymbol{\nabla}$ springeropen.com 